brother, Lt.-Col. M. M. Bidder, pointed out to me, every annual class in the local school of engineers would, in its turn, verify the meridian line under the supervision of their instructors; yet the second pyramid has the same orientation ( $5 \frac{1}{2}^{\prime}$ west of north) as the core-plane of the first pyramid.

There are five meridians deduced by Petrie (p. 4I) from his measurements. Of these the lowest and highest values occur in the Great Pyramid, being $-3^{\prime} 43^{\prime \prime} \pm 6^{\prime \prime}$ for the casing sides and $-5^{\prime} 49^{\prime \prime} \pm 7^{\prime \prime}$ for the passage. The four of them representing the Great Pyramid core and passage, and the Second Pyramid casing and passage, are all covered by the value $-5^{\prime} 33^{\prime \prime} \pm I 7^{\prime \prime}$. Petrie's conclusion (p. II) is "that the original base was probably more accurate than 0.65 inch in length and $\mathrm{I} 2$ " in angle."

GEORge P. BIDdER.

Cambridge, February 26.

THE undoubted trend of the pyramids at 4600 B.C. was about $5^{\prime}$ west of the present pole. Each of the data was probably set out afresh from polar observation, as that would be easier than transfer by measurement. The accuracy of work there to $I 2^{\prime \prime}$ of angle is in keeping with the accuracy of later work, as of granite planes 20 square feet in area with only inch/r6o error at 3300 B.C., or of weights in eighth century A.D. with variations all within grain/200. The cause of a change of axis of about $5^{\prime \prime}$ per century might be due to ocean currents or to earth deformation.

$$
\text { W. M. F. Petrie. }
$$

\section{Science and Armaments.}

DR. French's reply (NATURE, February Io) to my letter in the issue of January 20 does not touch upon the essential idea which I desired to express. I did not raise the question of the dispensability or indispensability of armaments at the present moment: a question on which a great deal might be said, but one which, I think, is somewhat outside the province of NATURE. The very columns of this journal are, however, a witness to a very real international brotherhood between men of all lands who find a common interest in the study of natural science and in its ceaseless warfare for the knowledge and control of material things for the common good of humanity.

Taking the wider view, how can it be a consolation that, under the urge of apparent national expediency, men should be spending their time in devising new methods of warfare by the application of that knowledge and training which should be a blessing to mankind instead of a curse ? The new weapon used against $\mathrm{A}$ by $\mathrm{B}$ is to-morrow directed by $\mathrm{A}$ against B. Moreover, these methods, the scientific cleverness and interest of which often provide a poor mask for their brutality, are directed, not against barbarism, but largely against those for whom we now profess friendship. Such a condition may be difficult to avoid, but the great danger is that we should treat it as natural and inevitable, and grow insensible to the shame of these things. Have we forgotten the folly of

$$
\text { "All valiant dust that builds on dust" ? }
$$

In the time of Davy it seems clear that science was respected as a thing apart from war, and we are led to inquire the reason for the change. Has it not been the willingness of inventors to exploit their knowledge, and to allow themselves to be exploited by men who cared less than nothing for science and all that it really stands for? There was small patriotism in many transactions that might be recalled, for things were sold to the highest bidder.
My first letter was, in brief, a plea that we should treat our science as something rare and precious, belonging not to ourselves only but also to all nations. Whatever burdensome and unpleasant tasks it may fall to our national lot to perform, we shall not face them the less effectively because we keep some of our most cherished possessions free from the dust of conflict. Hence my comment on the proposed action at the Science Museum.

Royal College of Science, South Kensington, S.W.7.

\section{Hafnium and Titanium.}

REFERRING to Sir Edward Thorpe's interesting letter on this subject in NATURE of February 24, I would point out that the Cornish village of "Manaccan " is in the parish of Manaccan, which adjoins the parish of St. Keverne. There is an error also in the spelling. "Menaccan" should be Manaccan, and so with the stream at "Lenarth," it should be Lanarth. Presumably, therefore, the Cornish mineral should have been called Manaccanite and not Menaccanite, and the "new element" from it should have been termed " manachin " and not " menachin."

Falmouth, February 26. WILSON L. Fox.

\section{The Gause of Anticyclones.}

IN a letter to NATURE of December 23 (vol. Iro, p. 845) Mr. W. H. Dines has raised certain questions connected with the cause of anticyclones. The chief observational facts to be explained are the features peculiar to most high pressures, namely, the warm troposphere, the high and cold stratosphere. But not all anticyclones are warm even from a height of $3 \mathrm{~km}$. up to $8 \mathrm{~km}$. Some are cold to considerable heights. The gradual rise of the coefficient of correlation between pressure and temperature at the same level as one proceeds from o to $4 \mathrm{~km}$., and the comparative uniformity of the coefficient from 4 to $8 \mathrm{~km}$., is in itself strong evidence that in our latitudes these first $4 \mathrm{~km}$. are the theatre of changes of air more and more frequent as the surface is approached, and that in the regions above $4 \mathrm{~km}$. the air is nearly always of one sort as regards its origin. Again, with regard to persistence, Hanslik pointed out that only the "warm" anticyclones are steady and slow moving; the "cold" ones move quickly. Further facts to be taken into account are, that the conception of an anticyclone as a region of great vertical stability and of fine bright weather appears to be correct as a rule only for the "warm " anticyclone. In the other type anything short of violent weather conditions may be experienced.

I have recently (Q. J. Roy. Met. Soc., January I923) put forward some evidence in support of the view that the explanation of the temperature peculiarities of the high- and low-pressure systems of our latitudes is, to a large extent, contained in the Bjerknes theory of their origin. In particular, when a pocket is made in the polar front by the southward rush of a great patch of polar air and when the pocket is afterwards closed behind this patch by the equatorial current from the south-west, the result is the formation of an anticyclone with closed isobars. From an examination of a more or less continuous series of upper-air observations I endeavoured to show that in such cases the change in barometric pressure at a given spot in the British Isles was indeed brought about by the fact that a thickness $h+\delta h$ of polar air had replaced a thickness $h$ of the equatorial current, and that the

$$
\text { NO. } 2787 \text {, VOL. I I I] }
$$

